\title{
Magnesium isotope fractionation reflects plant response to magnesium deficiency in magnesium uptake and allocation: a greenhouse study with wheat
}

\author{
Yi Wang • Bei Wu • Anne E. Berns • Ying Xing • Arnd \\ J. Kuhn • Wulf Amelung
}

Received: 19 July 2019 / Accepted: 12 June 2020 / Published online: 17 August 2020

(C) The Author(s) 2020

\begin{abstract}
Aims Magnesium (Mg) deficiency is detrimental to plant growth. However, how plants respond to $\mathrm{Mg}$ deficiency via regulation of $\mathrm{Mg}$ uptake and allocation is yet not fully understood. In this study, we tested whether $\mathrm{Mg}$ isotope compositions $\left(\delta^{26} \mathrm{Mg}\right.$ ) associated with $\mathrm{Mg}$ mass balance of the plants could be used as an indicator to trace Mg uptake and subsequent translocation processes under sufficient and low-Mg supply conditions. We aimed at using stable isotope fractionation as a novel proxy for nutrient uptake and cycling in plants.
\end{abstract}

\section{Responsible Editor: Ismail Cakmak}

Electronic supplementary material The online version of this article (https://doi.org/10.1007/s11104-020-04604-2) contains supplementary material, which is available to authorized users.

Y. Wang $\cdot$ B. Wu $\cdot$ A. E. Berns $\cdot$ Y. Xing $\cdot$ W. Amelung Institute of Bio- and Geosciences: Agrosphere (IBG-3), Forschungszentrum Jülich GmbH, 52425 Jülich, Germany

Y. Wang $(\bowtie)$

Institute for Environmental Research, Biology 5, RWTH Aachen University, 52074 Aachen, Germany

e-mail: wangy936@mail.sysu.edu.cn

\section{A. J. Kuhn}

Institute of Bio- and Geosciences: Plant Science (IBG-2),

Forschungszentrum Jülich GmbH, 52425 Jülich, Germany

W. Amelung

Institute of Crop Science and Resource Conservation (INRES), Soil Science and Soil Ecology, University of Bonn, 53115 Bonn, Germany
Methods We grew wheat plants (Triticum aestivum) in a greenhouse under control (1 $\mathrm{mM} \mathrm{Mg}$ ) and low-Mg supply $(0.05 \mathrm{mM} \mathrm{Mg})$ conditions, respectively. The $\mathrm{Mg}$ concentrations and isotope compositions in roots, stems, leaves and spikes/grains at different growth stages were analyzed.

Results Wheat plants were systematically enriched in heavy $\mathrm{Mg}$ isotopes relative to the nutrient solution regardless of $\mathrm{Mg}$ supply conditions. With crop growth, the $\delta^{26} \mathrm{Mg}$ of the whole plants, as well as each plant organ, gradually shifted towards higher values in the control. However, the $\delta^{26} \mathrm{Mg}$ value of the whole plants in the low-Mg supply did not vary significantly. In addition, the wheat stems and spikes showed continuous enrichment of lighter $\mathrm{Mg}$ isotopes in the low-Mg supply than those in the control.

Conclusions As reflected from $\mathrm{Mg}$ isotope compositions, the Mg supply in the growth media could affect the $\mathrm{Mg}$ uptake and subsequent translocation processes in plants. Changes in $\delta^{26} \mathrm{Mg}$ indicated that wheat plants likely regulated their $\mathrm{Mg}$ uptake strategy by switching between active and passive pathways during their life cycle. When $\mathrm{Mg}$ supply was low, a more negative $\delta^{26} \mathrm{Mg}$ value of the spikes suggested a potentially enhanced remobilization of $\mathrm{Mg}$ from leaves to spikes. Our results showed that $\mathrm{Mg}$ stable isotopes can provide new insights into plants' response to nutrient shortage.

Keywords $\mathrm{Mg}$ deficiency $\cdot \mathrm{Low}-\mathrm{Mg}$ supply $\cdot \mathrm{Mg}$ isotope compositions $\left(\delta^{26} \mathrm{Mg}\right) \cdot$ Root uptake $\cdot$ Root-shoot transport $\cdot \mathrm{Mg}$ remobilization 


\section{Abbreviations \\ ICP- inductively coupled plasma mass \\ MS spectrometry}

\section{Introduction}

Magnesium $(\mathrm{Mg})$ is one of the essential macronutrients for plants, playing a key role in many biochemical processes, especially in photosynthesis as the central atom in chlorophyll (Maguire and Cowan 2002; Willows 2007). Moreover, $\mathrm{Mg}$ is necessary for a series of enzyme activities and for protein synthesis, functioning as a bridge element between enzymes and substrates, for example, in the synthesis of ATP (Marschner 2011; Shaul 2002). Recent studies have also revealed a role of $\mathrm{Mg}$ in alleviating negative effects under adverse growth conditions, such as aluminum and manganese toxicity (Bose et al. 2011; Gransee and Führs 2013), photooxidative damage (Cakmak and Kirkby 2008), and heat stress (Mengutay et al. 2013). Therefore, $\mathrm{Mg}$ availability may significantly affect both productivity and quality of agricultural and horticultural crops (Gransee and Führs 2013; Hermans et al. 2005). Nevertheless, Mg deficiency is increasingly observed worldwide in forest and agricultural ecosystems, particularly in soils intensively fertilized with $\mathrm{K}^{+}$and $\mathrm{NH}_{4}{ }^{+}$, or in soils with low $\mathrm{pH}$ due to the potential loss of $\mathrm{Mg}$ by leaching (Cakmak and Yazici 2010; Guo et al. 2016).

When $\mathrm{Mg}$ is not supplied in sufficient amounts, a series of Mg-deficiency symptoms (e.g. interveinal chlorosis) appear: the photosynthetic rate and the export of sucrose from leaves via phloem decreases, leading to accumulation of carbohydrates in source leaves and growth inhibition of sink organs (Verbruggen and Hermans 2013). In order to obtain and preserve high contents of $\mathrm{Mg}$ in plants, in particular when $\mathrm{Mg}$ supplies are limited, plants have developed efficient physiological systems for Mg uptake and internal translocation (Hermans et al. 2013). For example, the MGT/MRS2 family of $\mathrm{Mg}$ transporters has been identified as the primary $\mathrm{Mg}$ transporters playing a key role in active $\mathrm{Mg}$ uptake by plants, e.g. Arabidopsis, rice and maize (Gebert et al. 2009; Li et al. 2001, 2016; Saito et al. 2013). Transport of Mg assisted with these transporters is considered as an active pathway which consumes energy and requires $\mathrm{Mg}$ firstly to be bound with membrane proteins during the cross-membrane transport of
$\mathrm{Mg}$ against concentration gradient (Chen et al. 2018). On the other hand, $\mathrm{Mg}$ is also thought to enter into root cells via passive pathways such as non-selective cation channels (Demidchik and Maathuis 2007; Ogura et al. 2018). In this case, Mg moves into the cells with the water stream driven by energy-free diffusion along concentration gradient (Hermans et al. 2013). Both the active and passive pathways can contribute to the root uptake of $\mathrm{Mg}$ during plant growth. However, which pathway dominates in the $\mathrm{Mg}$ uptake processes regulated by plants, especially when plants are grown under different $\mathrm{Mg}$ supply conditions or at different growth stages, still remains unknown.

Recent studies on biotic-induced $\mathrm{Mg}$ isotope fractionations have provided new insights into the physiological activities of plants (Schmitt et al. 2012; Teng 2017). Apparent differences in Mg isotope composition have been reported between plants and their environments in previous studies as a result of plant uptakeinduced $\mathrm{Mg}$ isotope fractionation (e.g. Black et al. 2008; Bolou-Bi et al. 2010, 2012; Opfergelt et al. 2014). Among these studies, Black et al. (2008) and Bolou-Bi et al. (2010) cultivated plants in pot experiments under greenhouse conditions as a model system, and demonstrated that $\mathrm{Mg}$ isotope compositions of the mature plants were heavier than those of the nutrient solution. The authors, however, only measured the Mg isotope compositions of plants grown with sufficient $\mathrm{Mg}$ supply at maturity stage. The dynamic $\mathrm{Mg}$ isotope fractionation during the plant life cycle under different $\mathrm{Mg}$ conditions still remains unclear. We hypothesize that when supplied with different amounts of $\mathrm{Mg}$, plants may regulate the $\mathrm{Mg}$ uptake through different combinations of the active and passive pathways. This may result in different $\mathrm{Mg}$ isotope compositions of the plants. In addition, $\mathrm{Mg}$ remobilization from older leaves to younger ones or reproductive organs (e.g. grain) during leaf senescence and grain filling play a more important role in plant growth when $\mathrm{Mg}$ is deficient in the growth media (Tiryakioğlu et al. 2014; Maillard et al. 2015; Billard et al. 2016; Peng et al. 2019). As Mg remobilization processes will change $\mathrm{Mg}$ isotope compositions of different plant organs (Kimmig et al. 2018), we further hypothesize that variation of $\mathrm{Mg}$ isotope compositions of plant organs can reflect $\mathrm{Mg}$ remobilization during plant growth.

Recent studies on biotic-induced $\mathrm{Mg}$ isotope fractionations have provided new insights into the physiological activities of plants (Schmitt et al. 2012; Teng 2017). 
Apparent differences in $\mathrm{Mg}$ isotope composition have been reported between plants and their environments in previous studies as a result of plant uptake-induced $\mathrm{Mg}$ isotope fractionation (e.g. Black et al. 2008; Bolou-Bi et al. 2010, 2012; Opfergelt et al. 2014). Among these studies, Black et al. (2008) and Bolou-Bi et al. (2010) cultivated plants in pot experiments under greenhouse conditions as a model system, and demonstrated that $\mathrm{Mg}$ isotope compositions of the mature plants were heavier than those of the nutrient solution. The authors, however, only measured the $\mathrm{Mg}$ isotope compositions of plants grown with sufficient $\mathrm{Mg}$ supply at maturity stage. The dynamic $\mathrm{Mg}$ isotope fractionation during the plant life cycle under different $\mathrm{Mg}$ conditions still remains unclear. We hypothesize that when supplied with different amounts of $\mathrm{Mg}$, plants may regulate the $\mathrm{Mg}$ uptake through different combinations of the active and passive pathways. This may result in different $\mathrm{Mg}$ isotope compositions of the plants. In addition, $\mathrm{Mg}$ remobilization from older leaves to younger ones or reproductive organs (e.g. grain) during leaf senescence and grain filling play a more important role in plant growth when $\mathrm{Mg}$ is deficient in the growth media (Tiryakioğlu et al. 2014; Maillard et al. 2015; Billard et al. 2016; Peng et al. 2019). As $\mathrm{Mg}$ remobilization processes will change $\mathrm{Mg}$ isotope compositions of different plant organs (Kimmig et al. 2018), we further hypothesize that variation of $\mathrm{Mg}$ isotope compositions of plant organs can reflect $\mathrm{Mg}$ remobilization during plant growth.

Therefore, in the present study we aimed to understand the role of $\mathrm{Mg}$ supplies in $\mathrm{Mg}$ isotope fractionation in plants, and how plants respond to $\mathrm{Mg}$ supplies during plant growth as indicated by variation of isotope compositions. Hence, we studied $\mathrm{Mg}$ isotope compositions of different organs of wheat plants grown under greenhouse conditions with either sufficient (control) or low-Mg supply, to elucidate the change of $\mathrm{Mg}$ isotope compositions of the plants in relation to varied uptake and remobilization processes of $\mathrm{Mg}$ under the two Mg supply conditions at different plant growth stages. We hypothesize that such isotopic data provide information on biological processes during $\mathrm{Mg}$ uptake and internal translocation.

\section{Materials and methods}

Plant growth and sampling

The seeds of summer wheat (Triticum aestivum) were germinated on a moistened filter paper in the dark for 48 h. Afterwards, well developed seedlings were selected and transferred into small pots filled with sterilized quartz sand (Quarzwerke Witterschlick GmbH, Witterschlick, Germany. 0.71-1.25 mm. $\mathrm{SiO}_{2}>98 \%$, $\mathrm{MgO}<0.1 \%$, w.) which had been pre-cleaned thoroughly with deionized water. In the first three days after transfer, the seedlings were watered without nutrient supply to allow them to adapt to the sand growing environment. Afterwards, the seedlings were placed into larger plastic pots containing sterilized quartz sand (2 plants per pot) and cultivated in controlled climatic environments until harvest (day/night rhythm 16/8 h, temperature $24 / 18{ }^{\circ} \mathrm{C}$, relative humidity $50-60 \%$, and light intensity $250 \mu \mathrm{mol} \mathrm{m} \mathrm{m}^{-2} \mathrm{~s}^{-1}$ supplied by fluorescent tubes). A modified $1 / 2$ Hoagland nutrient solution (Table S1, Online Resource) was used to supply nutrients for plant growth. Compared with sufficient $\mathrm{Mg}$ supply ( $1 \mathrm{mM} \mathrm{Mg}$, the control), $5 \%$ of the $\mathrm{Mg}$ concentration $(0.05 \mathrm{mM} \mathrm{Mg})$ was provided to the plants as the low-Mg supply. Before flowering (46 days after seedling), the nutrient solutions were supplied three times a day ( $9 \mathrm{am}, 1 \mathrm{pm}$, and $5 \mathrm{pm}$, respectively) at a rate of 30 $\mathrm{mL} \min ^{-1}$ for one minute each time per pot via a pump controlled by a timer (Fig. S1, Online Resource). After flowering, another $30 \mathrm{~mL}$ nutrient solution was applied for the 4th time at 8 pm additionally in order to account for the increased water demand of the plants. To check whether changes of $\mathrm{Mg}$ speciation in the nutrient solution might have occurred when varying the Mg concentrations, the chemical equilibrium model Visual MINTEQ v3.0 software was used. The contribution of the deionized water and quartz sand to plant uptake of $\mathrm{Mg}$ was also evaluated, respectively (Chap. 1 and 2, Online Resource). Results showed that the sandreleased $\mathrm{Mg}$ did not interfere the $\mathrm{Mg}$ isotope composition of the nutrient solution. For better illustration, the $\mathrm{Mg}$ isotope composition of sand-released $\mathrm{Mg}$ was not shown in the figures.

To study Mg isotope fractionation during the growth stages, wheat plants were sampled when they were in booting, flowering, post-flowering and at maturity (39, 46, 67 and 82 days after seedling, respectively). Four pot replicates were set for both the control and the low-Mg supply at each sampling time. In the low-Mg supply, due to the premature death of plants in three of the four pots, there was only one pot in which plants were still alive and sampled at maturity stage without replicates. Upon sampling, the two wheat plants in each pot were carefully taken out together with the sand which was 
then washed off with running deionized water. The two wheat plants were then separated into roots, stems, leaves, and spikes and the respective organs of both two plants were pooled into one replicate per pot. At the stage of maturity, grains were isolated from their bran instead of full spikes as done in the previous stages. All plant samples were lyophilized and milled to powder in a custom-designed ball mill (Shaker Viba 330, Collomix GmbH, Germany) using metal-free plastic bottles and tungsten carbide milling balls.

Sample preparation, Magnesium purification and isotope analysis

About $50 \mathrm{mg}$ plant materials were weighed in Teflon tubes and digested in a mixture of $3 \mathrm{ml}$ ultrapure $\mathrm{HNO}_{3}(68 \%)$ and $1 \mathrm{ml} \mathrm{H}_{2} \mathrm{O}_{2}(30 \%$, p.a.) in a pressurized microwaveassisted acid digestion system (turboWAVE® Inert, Milestone Srl, Italy). Elemental concentrations were analyzed by inductively coupled plasma mass spectrometry (ICPMS, Agilent 7900, Germany).

The $\mathrm{Mg}$ purification procedures were performed in a customer-designed laminar flow box in a cleanroom at the Agrosphere Institute at Forschungszentrum Jülich $\mathrm{GmbH}$. An aliquot of digested solution was evaporated to dryness on a hot plate at $90{ }^{\circ} \mathrm{C}$. The dried sample material was re-dissolved in $2 \mathrm{ml} 1 \mathrm{M}$ ultrapure $\mathrm{HNO}_{3}$. The separation of $\mathrm{Mg}$ from matrix elements was carried out by cation exchange chromatography using modified procedures of Teng et al. (2007) and Wombacher et al. (2009) (Table S2, Online Resource). Full recovery of $\mathrm{Mg}(>95 \%)$ and the absence of matrix elements were validated by analyzing their concentrations in the eluted $\mathrm{Mg}$ solution. Magnesium isotope ratios were measured on a multi-collector ICP-MS (MC-ICP-MS, Nu Plasma II, Nu Instruments Ltd., UK). To correct instrumental mass bias, a strategy of standard-sample-standard bracketing was applied with matched $\mathrm{Mg}$ concentrations between the standard and the samples (difference $<5 \%$ ). Magnesium isotope standard NIST SRM 980 was used as the bracketing standard in the present work. Therefore, the measured $\mathrm{Mg}$ isotope ratios of a sample were then converted to the $\delta$ notation as follows:

$\delta^{\mathrm{X}} \mathrm{Mg}(\% \circ)=\left[\frac{\left(\mathrm{x}_{\mathrm{Mg}} /{ }^{24} \mathrm{Mg}\right)_{\text {sample }}}{\left(\mathrm{x}_{\mathrm{Mg}} /{ }^{24} \mathrm{Mg}\right)_{\text {NIST980 }}}-1\right]$

$\times 100$ where $\mathrm{x}$ represents 25 or 26 . The three-isotope-plot, generated by the measured $\delta^{26} \mathrm{Mg}$ and $\delta^{25} \mathrm{Mg}$ values, indicated the absence of mass-independent isotope fractionation during the experiments and interference-free measurement during the analytical session (Fig. S2, Online Resource).

However, as the Mg isotope composition of NIST SRM 980 may differ in individual dispatches (Galy et al. 2003), we measured Mg isotope composition of our NIST SRM 980 relative the DSM3 (Dead Sea Magnesium, Galy et al. 2003), at the Institute of Geology and Mineralogy at University of Cologne, Germany, $\left(\delta^{26} \mathrm{Mg}_{\text {DSM3 }}^{\text {NIST980 }}=+3.91 \pm 0.09 \%\right.$, 2SD, $\left.\mathrm{n}=12\right)$. In the following sections, the $\delta^{26} \mathrm{Mg}$ values of our samples are then reported relative to the DSM3 with the conversion using the equation in Young and Galy (2004):

$$
\begin{aligned}
\delta^{26} \mathrm{Mg}= & \delta^{26} \mathrm{Mg}_{\mathrm{NIST} 980}^{\text {sample }}+\delta^{26} \mathrm{Mg}_{\mathrm{DSM}}^{\mathrm{NIST} 380}+0.001 \\
& \cdot \delta^{26} \mathrm{Mg}_{\mathrm{NIST} 980}^{\text {sample }} \cdot \delta^{26} \mathrm{Mg}_{\mathrm{DSM} 3}^{\text {NIST980 }}
\end{aligned}
$$

Data calculation \& Statistics

The $\mathrm{Mg}$ isotope compositions of aboveground shoot $\left(\delta^{26} \mathrm{Mg}_{\text {Shoot }}\right)$ and of the whole plant $\left(\delta^{26} \mathrm{Mg}_{\text {Plant }}\right)$ were calculated based on mass balance using:

$\delta^{26} \mathrm{Mg}_{\text {ShootorPlant }}=\sum\left(\delta^{26} \mathrm{Mg}_{\mathrm{i}} \times \frac{\mathrm{m}_{\mathrm{i}} \mathrm{c}_{\mathrm{i}}}{\sum \mathrm{m}_{\mathrm{i}} \mathrm{c}_{\mathrm{i}}}\right)$

where $m_{i}, c_{i}$, and $\delta^{26} \mathrm{Mg}_{\mathrm{i}}$ were the dry biomass, the $\mathrm{Mg}$ concentration, and $\mathrm{Mg}$ isotope composition of the plant organ $i$ (root, stem, leaf, or spike), respectively. Similarly, The Mg isotope composition of the spike at the stage of maturity, where the grain and the spelt had been separated during sampling, were calculated with the data of the spelt and the grain (Table S3, Online Resource) using this mass balance equation.

The apparent difference of $\mathrm{Mg}$ isotope composition between different $\mathrm{Mg}$ pools (i.e. $\mathrm{Mg}$ in nutrient solution, the plant organs and the whole plant) was calculated using:

$\Delta^{26} \mathrm{Mg}_{\mathrm{A}-\mathrm{B}}^{=} \delta^{26} \mathrm{Mg}_{\mathrm{A}}-\delta^{26} \mathrm{Mg}_{\mathrm{B}}$

The plant biomass, $\mathrm{Mg}$ concentrations and isotope compositions of the plant organs were presented as the mean values with the standard deviation (SD) of the four pot replicates. The $\mathrm{Mg}$ isotope composition of the 
nutrient solution was given as the mean $\pm \mathrm{SD}$ of three sample replicates. As the $\mathrm{Mg}$ isotope composition of the sand-released $\mathrm{Mg}$ was identical within error to that of the nutrient solution, we used the $\delta^{26} \mathrm{Mg}$ value of the nutrient solution to compare with those of the plants in the following sections.

Statistical analyses were performed in SPSS Statistics (Version 22; IBM Corp.). We used a two-sample ttest to test whether the $\mathrm{Mg}$ concentration and isotope composition of samples in the control were significantly different from that in the low-Mg supply $(p<0.05)$. To test the significances of differences in $\mathrm{Mg}$ concentration and isotope composition of samples among the growth stages in the control or the low-Mg supply, the Fisher's LSD procedure and Duncan's multiple range test (DMRT) were applied $(p<0.05)$.

\section{Results}

\section{Magnesium accumulation in plants}

Magnesium concentrations of wheat plants in the control $\left(1413 \pm 49\right.$ to $\left.2284 \pm 137 \mathrm{mg} \mathrm{kg}^{-1}\right)$ were significantly higher than those in the treatments with low-Mg supply (451 \pm 12 to $617 \mathrm{mg} \mathrm{kg}^{-1}$ ) (Table S3). The mass of $\mathrm{Mg}$ in each plant organ was shown in Fig. 1 as calculated by multiplying the $\mathrm{Mg}$ concentration with the dry biomass (Table S3, Online Resource). Wheat shoots in the control and the low-Mg supply both showed continuous accumulation of $\mathrm{Mg}$ during plant growth. Especially after the flowering stage, the shoots accumulated significantly larger amounts of $\mathrm{Mg}$ than the roots (Fig. 1). With regard to each plant organ, both leaves and spikes contained significantly more $\mathrm{Mg}$ than roots and stems of the control (Fig. 1). At maturity, leaves and spikes in the control accumulated over $44.4 \%$ and $42.3 \%$ of the total $\mathrm{Mg}$ in the plants, respectively (Fig. 1). Conversely, in the low-Mg supply wheat spikes accumulated most of $\mathrm{Mg}$, accounting for $73.7 \%$ of the total Mg in wheat plants at maturity (Fig. 1), while the $\mathrm{Mg}$ mass in the leaves showed no significant increase during plant growth (Fig. 1).

\section{Magnesium isotope composition in plants}

Preferential uptake of heavy $\mathrm{Mg}$ isotopes by plants was observed regardless of the amounts of the supplied $\mathrm{Mg}$.
Compared with the nutrient solution $\left(\delta^{26} \mathrm{Mg}=-2.70 \pm\right.$ $0.06 \%$ ), wheat plants exhibited heavier $\mathrm{Mg}$ isotope compositions in both control $\left(\delta^{26} \mathrm{Mg}_{\text {whole plant }}\right.$ ranged from $-2.08 \pm 0.04$ to $-1.28 \pm 0.16 \%$ ) and low-Mg supply $\left(\delta^{26} \mathrm{Mg}_{\text {whole plant }}\right.$ ranged from -1.73 to $-1.47 \pm$ $0.04 \%$ o). However, the apparent difference in $\mathrm{Mg}$ isotope compositions between the plant and the nutrient solution $\left(\Delta^{26} \mathrm{Mg}_{\text {plant-solution }}\right)$ varied in the two treatments. In the control, $\mathrm{Mg}$ isotope compositions of the wheat plants became increasingly heavier during the growth stages (Fig. 2). The enrichment of heavy $\mathrm{Mg}$ isotopes in plants during growth was observed to go along with the increases in $\delta^{26} \mathrm{Mg}$ values of each individual plant organ (Fig. 3). However, in the low-Mg supply treatment, the $\mathrm{Mg}$ isotope composition of the wheat plants did not change as the growth proceeded, with a relatively constant $\delta^{26} \mathrm{Mg}_{\text {whole plant }}$ value of about $-1.60 \%$. It was always $1.10 \%$ o heavier than that in the nutrient solution (Fig. 2). The constant $\delta^{26} \mathrm{Mg}_{\text {whole plant }}$ values were not reflected by the $\delta^{26} \mathrm{Mg}$ values of each individual plant organ. The evolvement of $\delta^{26} \mathrm{Mg}$ values during plant growth differed among plant organs (Fig. 3). Nevertheless, regardless of $\mathrm{Mg}$ conditions in the nutrient solution, the leaves exhibited the lightest $\mathrm{Mg}$ isotope compositions among all plant organs (Fig. 3). In addition, the aboveground shoots always showed lower $\delta^{26} \mathrm{Mg}$ values compared with the roots at all growth stages, displaying a favor of lighter $\mathrm{Mg}$ isotopes during root-shoot transport (Table S3, Online Resource).

\section{Discussion}

Magnesium isotope fractionation by root uptake

The apparent difference in $\mathrm{Mg}$ isotope compositions between the whole plants and the nutrient solution $\left(\Delta^{26} \mathrm{Mg}_{\text {plant-solution }}\right)$ was associated with the Mg uptake process by the plant (Bolou-Bi et al. 2010). Even though the investigated wheat plants in the two treatments were both enriched in heavy $\mathrm{Mg}$ isotopes relative to the nutrient solution, the change of $\Delta^{26} \mathrm{Mg}_{\text {plant-solution in }}$ the control differed from that in the low-Mg supply treatment (Fig. 2). The continuously increasing values of $\Delta^{26} \mathrm{Mg}_{\text {plant-solution }}$ in the control indicated a pronounced $\mathrm{Mg}$ isotope fractionation due to the uptake by the rising consumption of heavy $\mathrm{Mg}$ isotopes from the unlimited $\mathrm{Mg}$ pool in the nutrient solution during plant 


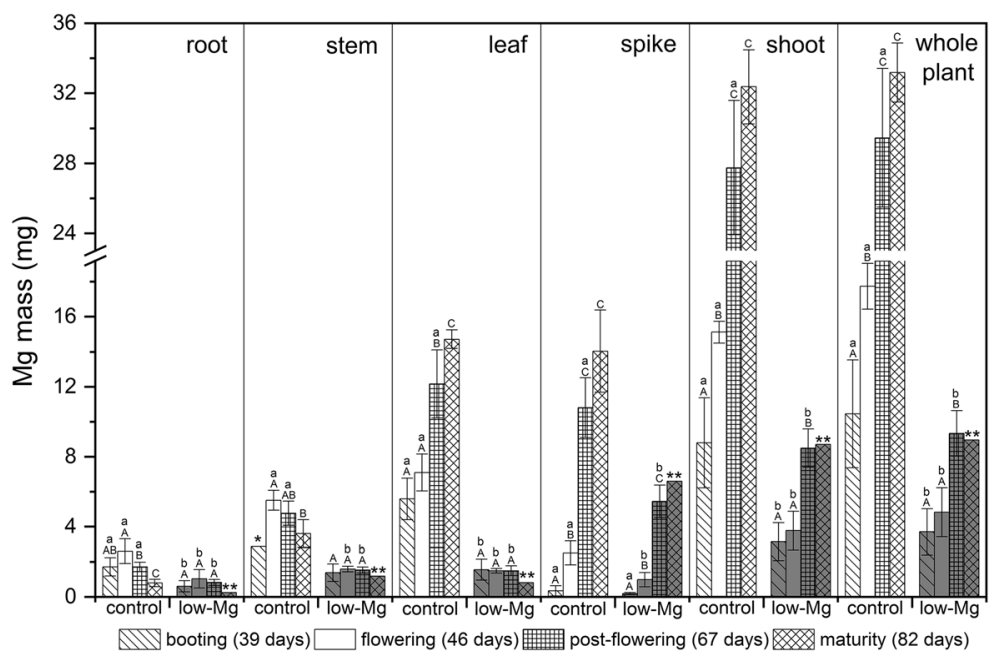

Fig. 1 Magnesium masses in each individual organs, the shoots and the whole plants during the growth stages under different $\mathrm{Mg}$ supplies: the control, $1 \mathrm{mM} \mathrm{Mg}$ (white); the low-Mg supply, $0.05 \mathrm{mM} \mathrm{Mg}$ (grey). Patterns in the bars represent different growth stage (from left to right: booting, flowering, post-flowering, maturity). Data are given as the mean $\pm \mathrm{SD}$ of four experimental replicates. Different capital letters denote statistically significant differences among growth stages in each treatment, while different lowercase letters indicate statistically significant differences between two treatments at the same growth stage $(p<0.05)$. *The $\mathrm{Mg}$ mass of stems at the booting stage in the control is given as suggested value (Chap. 4, Online Resource). **Because there was only one data group available at maturity in low-Mg supply, statistical evaluation with regard to this data group was not conducted

two pathways may result in different $\mathrm{Mg}$ isotope compositions of the whole plant, as binding with organic molecules is known to induce an enrichment of heavy $\mathrm{Mg}$ isotopes in Mg-organic complexes, as proven by previous studies based on both laboratory experiments and theoretical calculations (e.g. Black et al. 2007; Bolou-Bi et al. 2010; Moynier and Fujii 2017; Pokharel et al. 2018). By contrast, cross-membrane transport of free $\mathrm{Mg}$ cations may only lead to limited isotope fractionation and thus limited difference in $\delta^{26} \mathrm{Mg}$ values between the whole plants and the growth media (Pokharel et al. 2017, 2018). Since a plant may utilize both pathways based on the vegetal demand for $\mathrm{Mg}$ and on the $\mathrm{Mg}$ availability in the growth media, the degree of $\mathrm{Mg}$ isotope fractionation induced by root uptake is thus further dependent on the participation of these two pathways as already observed in rice (Cai et al. 2012; Tanoi et al. 2014). In the present study, the wheat plants in the control exhibited a $\mathrm{Mg}$ isotope composition close to the nutrient solution at the booting stage (Fig. 2). This indicates that the passive transport pathway was likely the dominant one. When plants grew older, their $\mathrm{Mg}$ demands consequently increased, and the active transport pathway played an increasing role in $\mathrm{Mg}$ uptake. The increasing involvement of the active transport pathway thus caused the $\delta^{26} \mathrm{Mg}_{\text {whole plant }}$ values to become 


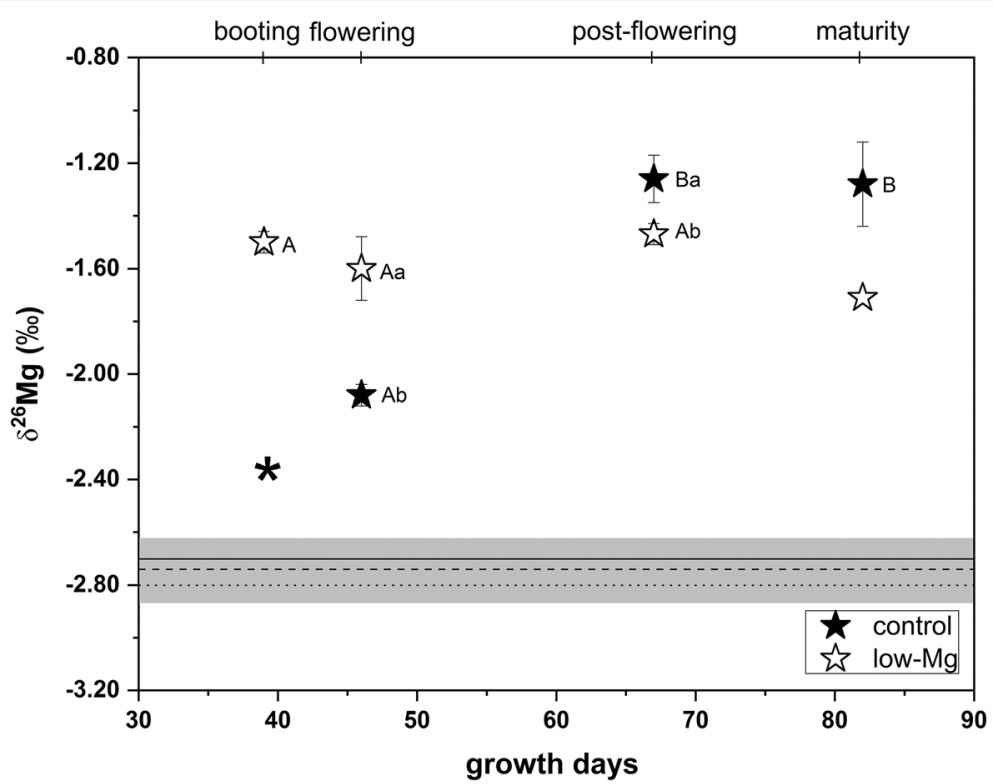

Fig. 2 Changes of $\mathrm{Mg}$ isotope compositions of the whole plants during the growth stages under different $\mathrm{Mg}$ supplies. Data are calculated based on mass balance equation (Eq. 3) and given as the mean $\pm \mathrm{SD}$ of four experimental replicates. Different capital letters denote statistically significant differences among growth stages in each treatment, while different lowercase letters indicate statistically significant differences between two treatments at the same growth stage $(p<0.05)$. The $\mathrm{Mg}$ isotope compositions of the

heavier during plant growth (Fig. 2). On the contrary, in the low-Mg supply, wheat plants displayed heavy $\mathrm{Mg}$ isotope compositions already at the booting stage (Fig. 2 ), reflecting that the active pathway was dominant in $\mathrm{Mg}$ uptake. Moreover, there was limited variation of $\Delta^{26} \mathrm{Mg}_{\text {plant-solution }}$ during plant growth. It indicated the active pathway to be the main strategy for $\mathrm{Mg}$ uptake along the life cycle of the wheat plants when $\mathrm{Mg}$ was supplied insufficiently.

Our data are in line with Tanoi et al. (2014) who reported that $\mathrm{Mg}$ uptake through active pathway was enhanced by $\mathrm{Mg}$ deficiency. They explained this finding by the fact that the plant requires $\mathrm{Mg}$ to sustain essential physiological functions even if this occurs at the expense of energy when Mg supply is limited. In addition, our results support the hypothesis that plants can modulate the uptake pathways by changing the participations of the passive and active pathways when the nutrient concentration varies (Epstein and Bloom 2005). However, it remains unclear that at which $\mathrm{Mg}$ concentration plants start to adjust the uptake pathways. Nevertheless, our data provide clear evidence that the $\mathrm{Mg}$ isotope composition of a plant, as well as its changes nutrient solution (solid line, $\delta^{26} \mathrm{Mg}_{\text {nutrient solution }}=-2.70 \pm 0.06 \%$ ) and of the exchangeable $\mathrm{Mg}$ pool in the quartz sand (dotted line, $\delta^{26} \mathrm{Mg}_{\text {sand-released }}=-2.81 \pm 0.11 \%$ o) are identical within error. The dashed line and the grey area (solid line, $\delta^{26} \mathrm{Mg}=-2.74 \pm 0.13 \%$ ) represent the $\delta^{26} \mathrm{Mg}$ of the mixed pool of $\mathrm{Mg}_{\text {sand-released }}$ and $\mathrm{Mg}_{\text {nutrient solution }}$ in the low-Mg supply (Chap. 2, Online Resource). *Estimated value of the $\delta^{26} \mathrm{Mg}_{\text {whole plant }}$ at the booting stage in the control (Chap. 4, Online Resource)

during plant growth, can directly reflect the uptake pathways, and thus indicate for the degree that whether cross-membrane transport is dominated by active, carrier-mediated transport mechanisms or by passive Mg-permeable channels. Directly correlating the extent of $\mathrm{Mg}$ isotope fractionation to the monitoring of the different transport pathways, however, warrants further investigation.

Speciation calculation with Visual MINTEQ v3.0 showed that in the nutrient solution, free $\mathrm{Mg}$ cations accounted for $96.5 \%$ and $99.7 \%$ of the total $\mathrm{Mg}$ content in the control and the low-Mg supply treatments, respectively. Hence, differences in the Mg speciation due to distinct $\mathrm{Mg}$ concentrations in nutrient solution were negligibly small if at all present between the two treatments. It is worth noting that the low-Mg supply may enhance the root exudation of organic acids with low molecular masses (Ohta and Hiura 2016). Such exudation processes alter the $\mathrm{Mg}$ availability in rhizosphere (Marschner et al. 1987). However, in the present study the exact amount of $\mathrm{Mg}$ from the sands and its $\mathrm{Mg}$ speciation utilized by plants was unknown. As both free $\mathrm{Mg}$ cations and $\mathrm{Mg}$-organic acid complexes can both be 


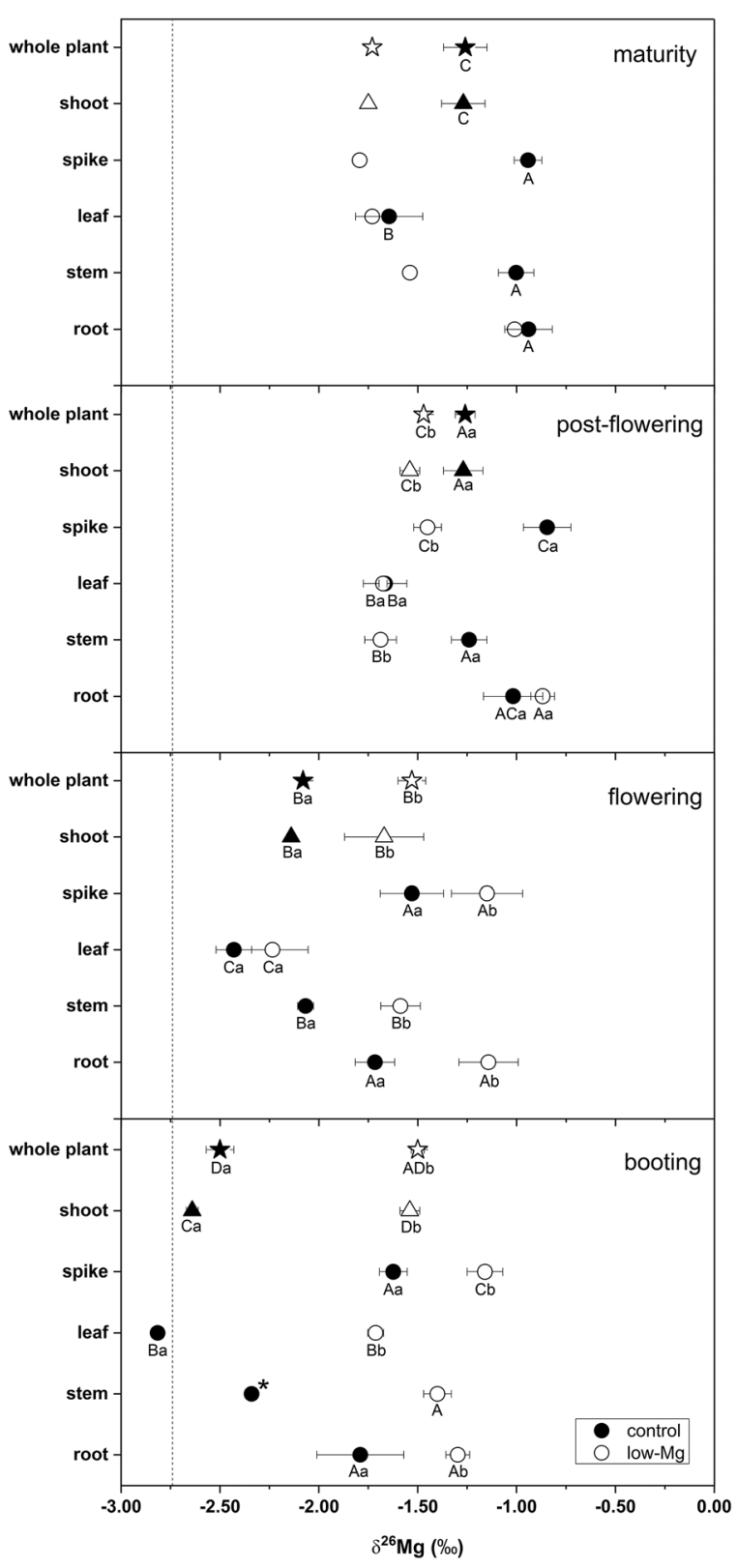

Fig. 3 Magnesium isotope compositions of plant organs, and of the shoots and the whole plants during the growth stages in the control (1 mM Mg) and the low-Mg supply (0.05 mM Mg). Data are given as the mean $\pm \mathrm{SD}$ of four experimental replicates. The vertical dashed line is the mean $\delta^{26} \mathrm{Mg}$ value $(-2.74 \pm 0.13 \%$ of the mixed pool of $\mathrm{Mg}_{\text {sand-released }}$ and $\mathrm{Mg}_{\text {nutrient solution }}$ (Chap. 2, Online Resource). Different capital letters at each growth stage denote statistically significant differences among plant organs in each treatment, while different lowercase letters at each growth stage indicate statistically significant differences of the same plant organs between two treatments $(p<0.05)$. *Estimation of the $\delta^{26} \mathrm{Mg}$ of the stem at the booting stage in the control is given in the Chap. 4, Online Resource taken up by roots, it seemed reasonable to assume that the $\mathrm{Mg}$ isotope composition of rhizospheric Mg-organic acid complexes varied within the pool of exchangeable $\mathrm{Mg}$ in the quartz sand (Chap. 2, Online Resource), and the root exudation would not significantly affect the root uptake-induced $\mathrm{Mg}$ isotope fractionation.

Magnesium isotope fractionation by root-shoot translocation

After entering in root cells, $\mathrm{Mg}$ can be loaded into the xylem rapidly and transported upwards with the transpiration stream to upper plant organs of active transpiration and photosynthesis, such as expanded leaves. Our results showed that such root-shoot translocation process fractionated $\mathrm{Mg}$ isotopes, leading to an enrichment of isotopically light $\mathrm{Mg}$ in the shoots relative to the roots in both treatments (Fig. 3). The positive values of $\Delta^{26} \mathrm{Mg}_{\text {root-shoot }}$ (Fig. 4), ranging from $+0.26 \pm 0.06$ to $+0.85 \pm 0.18 \%$ for the control and from $+0.24 \pm 0.08$ to $+0.74 \pm 0.00 \%$ o for the low-Mg supply, respectively, corresponded on the same order of magnitude to the results of previous studies on rye grass (Bolou-Bi et al. 2010) and rice (Gao et al. 2018). However, changes of $\Delta^{26} \mathrm{Mg}_{\text {root-shoot }}$ with plant growth in the low-Mg supply differed from those in the control (Fig. 4). The values of $\Delta^{26} \mathrm{Mg}_{\text {root-shoot }}$ in the low-Mg supply increased by $0.5 \%$ from booting to maturity, while those in the control decreased with plant growth. Such contrary evolvements of $\Delta^{26} \mathrm{Mg}_{\text {root-shoot }}$ indicated that low-Mg supply did not only affect the root uptake of $\mathrm{Mg}$ but also the upwards translocation of $\mathrm{Mg}$ from root to shoot. As $\mathrm{Mg}$ is transferred from roots to shoots through xylem loading, the apparent difference of $\mathrm{Mg}$ isotope compositions between roots and shoots was thus likely resulted from the xylem loading process. However, the exact mechanism answering for xylem $\mathrm{Mg}$ loading remains unclear (Chen et al. 2018). To date, several transport systems are suggested to regulate $\mathrm{Mg}$ entering into the xylem vessels (Hermans et al. 2013). First, MRS/MGTfamily protein (implicating AtMRS2-2) is involved in xylem loading process in rice roots as verified by Tanoi et al. (2011). Second, one of the cyclic nucleotide-gated channels, CNGC10 in mature Arabidopsis plants, has also been reported to be capable of transporting $\mathrm{Mg}$ cations into the xylem ( $\mathrm{Li}$ et al. 2005; Guo et al. 2010). Finally, the $\mathrm{Mg} / \mathrm{H}^{+}$Exchanger 1 localized in the vacuolar membrane may control the amount of $\mathrm{Mg}$ that stored in the cytosol of parenchyma cells for xylem 
Fig. 4 Apparent differences of $\mathrm{Mg}$ isotope compositions between the roots and the shoots $\left(\Delta^{26} \mathrm{Mg}_{\text {root-shoot }}\right)$ in the control ( $1 \mathrm{mM} \mathrm{Mg}$, solid circles) and in the low-Mg supply $(0.05 \mathrm{mM}$ $\mathrm{Mg}$, open circles) during plant growth. Data are given as the mean \pm SD of four experimental replicates. Different capital letters denote statistically significant differences among growth stages in each treatment, while different lowercase letters indicate statistically significant differences between two treatments at the same growth stage $(p<0.05)$

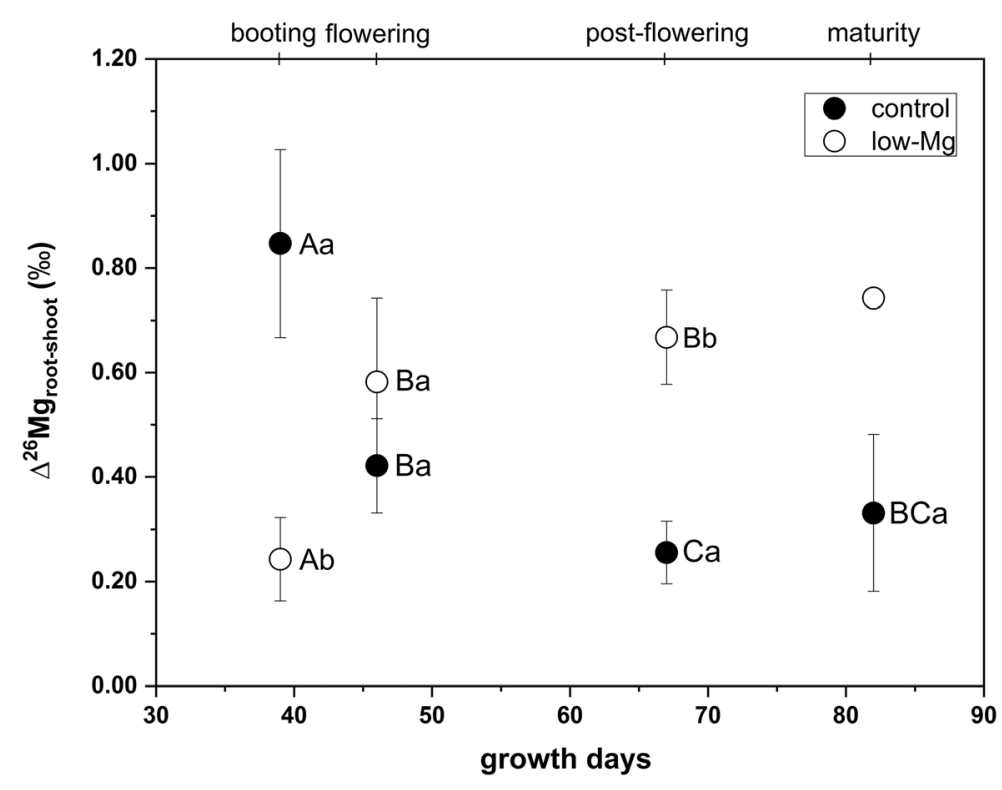

loading (Shaul et al. 1999; Kobayashi and Tanoi 2015). It can be inferred from our data that similar to the root uptake of $\mathrm{Mg}$, these systems presumably also have different preference of light or heavy $\mathrm{Mg}$ isotopes. In this case, the $\mathrm{Mg}$ isotope fractionation induced by xylem loading process is thus determined by the $\mathrm{Mg}$ speciation (Mg-organic complexes or free cations) during membrane transport. If $\mathrm{Mg}$ is first bound to membrane proteins and then transported as Mg-organic complexes, the $\mathrm{Mg}$ pool in the xylem is presumed to become isotopically heavier. On the contrary, direct transport of free $\mathrm{Mg}$ cations likely induces limited variation or a negative shift of the $\delta^{26} \mathrm{Mg}$ values in the xylem. In addition, the participation of each pathway in xylem loading may vary depending on the level of supplied $\mathrm{Mg}$ for plant growth that can also change the $\mathrm{Mg}$ isotope composition in xylem sap. We thus envision that specific measurements of $\mathrm{Mg}$ isotope compositions in e.g. the xylem sap and the cytosol of xylem parenchyma cells could help clarify the xylem loading process of $\mathrm{Mg}$ under different Mg conditions.

Magnesium isotope fractionation during grain filling by remobilization

During grain filling, the wheat spikes in both the control and the low-Mg supply displayed a remarkable accumulation of more $\mathrm{Mg}$ than at the booting growth stage (Fig. 1), indicating a higher demand for nutrients in the productive organs at reproductive growth stage. However, accumulation of $\mathrm{Mg}$ in wheat leaves at the booting stage was only observed in the control (Fig. 1). Low-Mg supply resulted in a limited variation of $\mathrm{Mg}$ mass in leaves (Fig. 1). By plotting the $\delta^{26} \mathrm{Mg}$ value as a function of $\mathrm{Mg}$ mass (Fig. 5), the $\mathrm{Mg}$ isotopes in the wheat spikes and leaves of the two treatments fractionated conversely with the plant growth. In the control, the wheat spikes showed an enrichment of heavy $\mathrm{Mg}$ isotopes, whereas the wheat spikes in the low$\mathrm{Mg}$ supply became isotopically lighter with increasingly accumulation of Mg (Fig. 5a). Wheat leaves in the control displayed similar trend to the spikes, while that in the lowMg supply was much different (Fig. 5b). Such distinct patterns of $\mathrm{Mg}$ isotope fractionation in wheat spikes and leaves in the two treatments indicated that the Mg source for grain filling differed, possibly due to the variation of Mg remobilization processes within plants under different $\mathrm{Mg}$ supplies. Reproductive organs such as grains typically exhibit high nutritional demand but a low transpiration rate. Hence, the spikes are expected to be mainly supplied with $\mathrm{Mg}$ through phloem transport instead of xylem transport (Hermans et al. 2013; Wiggenhauser et al. 2018; Pearson et al. 1995). The Mg isotope composition of the phloem therefore directly affects that of the reproductive organs. As phloem-mobile element, $\mathrm{Mg}$ can be remobilized from older leaves to younger leaves or reproductive organs after chlorophyll decomposition during leaf senescence (Langmeier et al. 1993, Nooden et al. 1997). A recent study by Peng et al. (2019) showed that limited Mg supply accelerated the process of chlorophyll breakdown 
Fig. 5 Relationships between $\mathrm{Mg}$ isotope compositions and $\mathrm{Mg}$ masses of the wheat spikes (a) and leaves (b) in the control (1 mM $\mathrm{Mg}$, solid symbols) and the lowMg supply (0.05 mM Mg, open symbols), respectively. The growth cycle of the plants is marked with arrows. Different symbols represent the growth stages of booting (circle), flowering (square), postflowering (triangle), and maturity (diamond), respectively. Data are given as the mean $\pm \mathrm{SD}$ of four experimental replicates
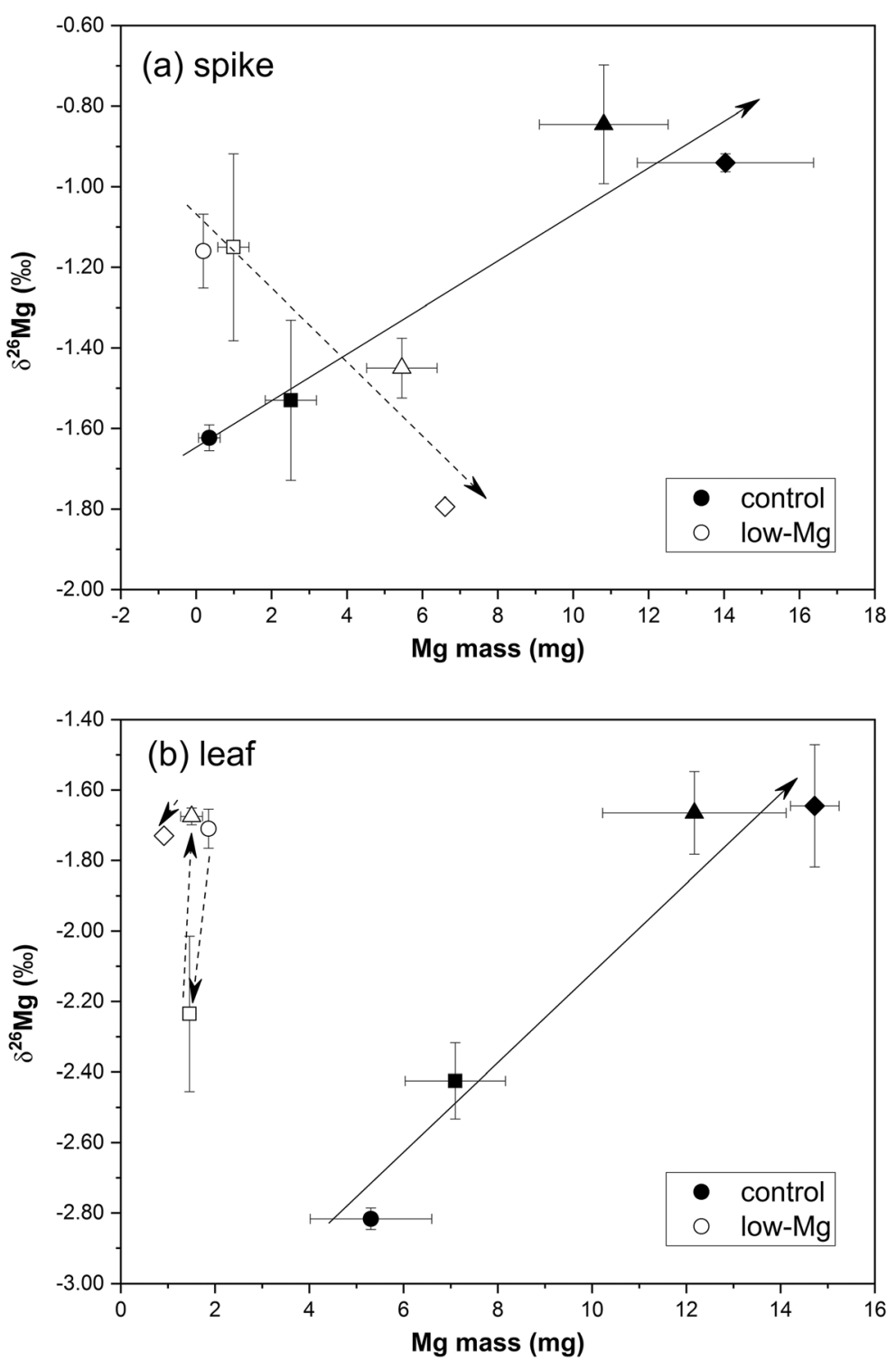

and subsequent release of $\mathrm{Mg}$ even from mid-aged leaves for $\mathrm{Mg}$ remobilization in rice. This suggests that, in our study, the remobilization of $\mathrm{Mg}$ was presumably already advanced at the flowering stage in the low-Mg supply, which induced a marked outflux of $\mathrm{Mg}$ from the leaves in this period. Compared with other plant organs, isotopically light $\mathrm{Mg}$, mainly located in chlorophylls, is usually enriched in the leaves (Galy et al. 2001; Young and Galy 2004; Black et al. 2006, 2008; Ra and Kitagawa 2007; Ra et al. 2010), which results in the leaves being isotopically the lightest among plant organs. Consequently, a breakdown of chlorophyll molecules can release isotopically light $\mathrm{Mg}$ into the phloem, leading to the phloem sap becoming enriched in light $\mathrm{Mg}$ isotopes. Due to the depletion of isotopically light $\mathrm{Mg}$, the $\delta^{26} \mathrm{Mg}$ value of $\mathrm{Mg}$ source (leaf) increased after flowering in the low-Mg supply, while the Mg sink (spike) became isotopically lighter as it was fed by the isotopically light $\mathrm{Mg}$ via the phloem transport (Fig. 3). In this regard our results agree with the study of Kimmig et al. (2018) who showed that yellow leaves of sugar maple exhibited higher $\delta^{26} \mathrm{Mg}$ values than the green ones as light $\mathrm{Mg}$ isotopes were preferentially remobilized from the $\mathrm{Mg}$ sources (already yellowed leaves). As wheat plants also take up additional $\mathrm{Mg}$ from the growth media during grain filling stage, it is difficult to quantify the in- and outflux of $\mathrm{Mg}$ in leaves. 
Unlike the control, the net-remobilization of $\mathrm{Mg}$ in leaves of the low-Mg supply seemed to be balanced after flowering, as suggested by the limited variation of $\mathrm{Mg}$ mass in leaves (Fig. 1). Therefore, the discrepancy in $\mathrm{Mg}$ isotope composition of wheat leaves and spikes indicated that different mechanisms were involved in the Mg remobilization processes under the two different $\mathrm{Mg}$ supplies.

Overall, our findings supported the hypothesis that $\mathrm{Mg}$ deficiency could enhance the remobilization processes of $\mathrm{Mg}$ from the source to sink organs through the phloem transport (Billard et al. 2016; Peng et al. 2019). When $\mathrm{Mg}$ is low in the growth media, the chlorophylls in leaves are expected to break down and release $\mathrm{Mg}$ to move towards the wheat spikes with the phloem sap. In this regard, analyzing the $\mathrm{Mg}$ isotope composition of each plant organ at different growth stages provides a novel and integrative tool to identify different $\mathrm{Mg}$ utilization patterns of the plants, which may also be used to study $\mathrm{Mg}$ acquisition and translocation strategies under field conditions without sophisticated transporter analyses. Noticeably, recent studies on $\mathrm{Zn}$ and $\mathrm{Cd}$ transport within rice showed that apart from the phloem transport of stored $\mathrm{Zn}$ and $\mathrm{Cd}$ from the leaves, xylem-to-phloem transfer at the stem nodes also played a role in mobilizing $\mathrm{Zn}$ and $\mathrm{Cd}$ to the grains via the phloem. This indicates that $\mathrm{Zn}$ and $\mathrm{Cd}$ could be loaded into the phloem and then directly transported into the grains without leaf storage (Nishiyama et al. 2013; Yoneyama et al. 2010, 2015). The direct influx of the elements from the xylem would then result in the isotope composition of the grains being different from that receiving the element remobilized from the leaves via phloem. Whether this kind of transport is also valid for $\mathrm{Mg}$ in wheat and its effect on $\mathrm{Mg}$ isotope compositions in the wheat spikes/grains warrants further studies.

\section{Implications}

Nowadays, $\mathrm{Mg}$ deficiency in plants occurs increasingly both in agriculture and forestry at a worldwide scale (Marschner 2011). However, plants can develop various strategies to deal with frequently encountered environmental stress like nutrient deficiencies (Cai et al. 2012). Our work traced the $\mathrm{Mg}$ isotope compositions of the widely grown agronomic crop wheat across its life cycle under both control and low-Mg supply conditions. Variations of the $\mathrm{Mg}$ isotope compositions in different plant organs demonstrated that different mechanisms were potentially involved in the plant's response to nutrient deficiency. The uptake of $\mathrm{Mg}$ was expected to be controlled by both active and passive pathways in the wheat root, with the active pathway dominating under low-Mg conditions throughout the life cycle of wheat plants. On the contrary, the wheat plants supplied with sufficient $\mathrm{Mg}$ altered the participations of these two pathways during plant growth depending on its $\mathrm{Mg}$ demand. In addition, low-Mg supply is expected to enhance the break-down of chlorophylls in the leaves, as well as the remobilization process of the released $\mathrm{Mg}$ from the leaves to spikes. To date, our knowledge about the contribution of different processes involved in the $\mathrm{Mg}$ uptake strategy, as well as the long-distance transport of $\mathrm{Mg}$ within plant is still limited. Our study showed that the evolvements of $\mathrm{Mg}$ isotope compositions of whole wheat plants and individual plant organs during growth reflected the utilization of distinct uptake pathways and distinct $\mathrm{Mg}$ remobilization processes within the plants, respectively. Studying stable isotopes combined with mass balance calculation can thus be a useful tool to assist the understanding of the molecular biology of phytophysiological activities, e.g., on how plants survive through strategic adjustment at different growth stages under limited nutrient supply, and to which extent different biological processes contribute to the plant growth.

Acknowledgements The first author appreciates the China Scholarship Council (CSC) for financial support. We also thank Beate Uhlig for provision of wheat seeds and technical assistance in growing the plants. Dr. Frank Wombacher at Institute of Geology and Mineralogy at University of Cologne is acknowledged for measuring $\delta^{26} \mathrm{Mg}$ of our NIST SRM 980 relative to the DSM3. This work was supported by the German Federal Ministry of Education and Research (BMBF) in the framework of the funding initiative "Soil as a Sustainable Resource for the Bioeconomy BonaRes", project "BonaRes (Module A): Sustainable Subsoil Management - Soil3; subproject 3" [grant numbers 031 B0515C, 2018]. We are grateful to the anonymous reviewers for their constructive comments and suggestions.

Funding Information Open Access funding provided by Projekt DEAL.

Open Access This article is licensed under a Creative Commons Attribution 4.0 International License, which permits use, sharing, adaptation, distribution and reproduction in any medium or format, as long as you give appropriate credit to the original author(s) and the source, provide a link to the Creative Commons licence, and indicate if changes were made. The images or other third party material in this article are included in the article's Creative Commons licence, unless indicated otherwise in a credit line to the material. If material is not included in the article's Creative Commons licence and your intended use is not permitted by statutory regulation or exceeds the permitted use, you will need to obtain 
permission directly from the copyright holder. To view a copy of this licence, visit http://creativecommons.org/licenses/by/4.0/.

\section{References}

Billard V, Maillard A, Coquet L, Jouenne T, Cruz F, Garcia-Mina JM, Yvin JC, Ourry A, Etienne P (2016) Mg deficiency affects leaf $\mathrm{Mg}$ remobilization and the proteome in Brassica napus. Plant Physiol Bioch 107:337-343

Black JR, Yin QZ, Casey WH (2006) An experimental study of magnesium-isotope fractionation in chlorophyll-a photosynthesis. Geochim Cosmochim Ac 70:4072-4079

Black JR, Yin QZ, Rustad JR, Casey WH (2007) Magnesium isotopic equilibrium in chlorophylls. J Am Chem Soc 129: 8690-8691

Black JR, Epstein E, Rains WD, Yin QZ, Casey WH (2008) Magnesium-isotope Fractionation During Plant Growth. Environ Sci Technol 42:7831-7836

Bolou-Bi EB, Poszwa A, Leyval C, Vigier N (2010) Experimental determination of magnesium isotope fractionation during higher plant growth. Geochim Cosmochim Ac 74:25232537

Bolou-Bi EB, Vigier N, Poszwa A, Boudot JP, Dambrine E (2012) Effects of biogeochemical processes on magnesium isotope variations in a forested catchment in the Vosges Mountains (France). Geochim Cosmochim Ac 87:341-355

Bose J, Babourina O, Rengel Z (2011) Role of magnesium in alleviation of aluminium toxicity in plants. J Exp Bot 62 : 2251-2264

Cai J, Chen L, Qu HY, Lian J, Liu W, Hu YB, Xu GH (2012) Alteration of nutrient allocation and transporter genes expression in rice under $\mathrm{N}, \mathrm{P}, \mathrm{K}$, and $\mathrm{Mg}$ deficiencies. Acta Physiol Plant 34:939-946

Cakmak I, Kirkby EA (2008) Role of magnesium in carbon partitioning and alleviating photooxidative damage. Physiol Plantarum 133:692-704

Cakmak I, Yazici AM (2010) Magnesium: a forgotten element in crop production. Better Crops 94:23-25

Chen ZC, Peng WT, Li J, Liao H (2018) Functional dissection and transport mechanism of magnesium in plants. Semin Cell Dev Biol 74:142-152

Demidchik V, Maathuis FJ (2007) Physiological roles of nonselective cation channels in plants: from salt stress to signalling and development. New Phytol 175:387-404

Epstein E, Bloom AJ (2005) Mineral nutrition of plants: principles and perspectives. Second. Sinauer Associates, Inc., Sunderland

Galy A, Belshaw N, Halicz L, O’Nions R (2001) High-precision measurement of magnesium isotopes by multiple-collector inductively coupled plasma mass spectrometry. Int J Mass Spectrom 208:89-98

Galy A, Yoffe O, Janney PE et al (2003) Magnesium isotope heterogeneity of the isotopic standard SRM980 and new reference materials for magnesium-isotope-ratio measurements. J Anal Atom Spectrom 18:1352-1356

Gao T, Ke S, Wang SJ, Li FB, Liu CS, Lei J, Liao CZ, Wu F (2018) Contrasting $\mathrm{Mg}$ isotopic compositions between FeMn nodules and surrounding soils: Accumulation of light $\mathrm{Mg}$ isotopes by $\mathrm{Mg}$-depleted clay minerals and $\mathrm{Fe}$ oxides. Geochim Cosmochim Ac 237:205-222

Gebert M, Meschenmoser K, Svidova S, Weghuber J, Schweyen R, Eifler K, Lenz H, Weyand K, Knoop V (2009) A RootExpressed Magnesium Transporter of the MRS2/MGT Gene Family in Arabidopsis thaliana Allows for Growth in Low$\mathrm{Mg}^{2+}$ Environments. Plant Cell 21:4018-4030

Gransee A, Führs H (2013) Magnesium mobility in soils as a challenge for soil and plant analysis, magnesium fertilization and root uptake under adverse growth conditions. Plant Soil 368:5-21

Guo KM, Babourina O, Christopher DA, Borsic T, Rengel Z (2010) The cyclic nucleotide-gated channel AtCNGC10 transports $\mathrm{Ca}^{2+}$ and $\mathrm{Mg}^{2+}$ in Arabidopsis. Physiol Plant 139:303-312

Guo WL, Nazim H, Liang ZS, Yang DF (2016) Magnesium deficiency in plants: An urgent problem. Crop J 4:83-91

Hermans C, Bourgis F, Faucher M, Strasser RJ, Delrot S, Verbruggen N (2005) Magnesium deficiency in sugar beets alters sugar partitioning and phloem loading in young mature leaves. Planta 220:541-549

Hermans C, Conn SJ, Chen JG, Xiao QY, Verbruggen N (2013) An update on magnesium homeostasis mechanisms in plants. Metallomics 5:1170-1183

Kimmig SR, Holmden C, Belanger N (2018) Biogeochemical cycling of $\mathrm{Mg}$ and its isotopes in a sugar maple forest in Quebec. Geochim Cosmochim Ac 230:60-82

Kobayashi N, Tanoi K (2015) Critical Issues in the Study of Magnesium Transport Systems and Magnesium Deficiency Symptoms in Plants. Int J Mol Sci 16:23076-23093

Kuhn AJ, Schröder WH, Bauch J (2000) The kinetics of calcium and magnesium entry into mycorrhizal spruce roots. Planta 210:488-496

Langmeier M, Ginsburg S, Matile Ph (1993) Chlorophyll breakdown in senescent leaves: demonstration of $\mathrm{Mg}$-dechelatase activity. Physiol Plant 89:347-353

Li LG, Tutone AF, Drummond RSM, Gardner RC, Luan S (2001) A novel family of magnesium transport genes in Arabidopsis. Plant Cell 13:2761-2775

Li X, Borsics T, Harrington HM, Christopher DA (2005) Arabidopsis AtCNGC10 rescues potassium channel mutants of E. coli, yeast and Arabidopsis and is regulated by calcium/ calmodulin and cyclic GMP in E. coli. Funct Plant Biol 32: 643-653

Li HY, Du HM, Huang KF, Chen X, Liu TY, Gao SB, Liu HL, Tang QL, Rong TZ, Zhang SZ (2016) Identification, and Functional and Expression Analyses of the CorA/MRS2/ MGT-Type Magnesium Transporter Family in Maize. Plant Cell Physiol 57:1153-1168

Maguire ME, Cowan JA (2002) Magnesium chemistry and biochemistry. Biometals 15:203-210

Maillard A, Diquélou S, Billard V, Laîné P, Garnica M, Prudent M et al (2015) Leaf mineral nutrient remobilization during leaf senescence and modulation by nutrient deficiency. Front Plant Sci 6:317

Marschner H (2011) Marschner's mineral nutrition of higher plants. Academic Press, London

Marschner H, Römheld V, Cakmak I (1987) Root-induced changes of nutrient availability in the rhizosphere. J Plant Nutr 10: 1175-1184 
Mengutay M, Ceylan Y, Kutman UB, Cakmak I (2013) Adequate magnesium nutrition mitigates adverse effects of heat stress on maize and wheat. Plant Soil 368:57-72

Moynier F, Fujii T (2017) Theoretical isotopic fractionation of magnesium between chlorophylls. Sci Rep-UK 7:1-6

Nishiyama R, Tanoi K, Yanagisawa S, Yoneyama T (2013) Quantification of zinc transport via the phloem to the grain in rice plants (Oryza sativa L.) at early grain-filling by a combination of mathematical modeling and ${ }^{65} \mathrm{Zn}$ tracing. Soil Sci Plant Nutr 59:750-755

Noodén L, Guiamét J, John I (1997) Senescence mechanisms. Physiol Plant 101:746-753

Ogura T, Kobayashi NI, Suzuki H, Iwata R, Nakanishi TM, Tanoi K (2018) Magnesium uptake characteristics in Arabidopsis revealed by ${ }^{28} \mathrm{Mg}$ tracer studies. Planta $248: 745-750$

Ohta T, Hiura T (2016) Root exudation of low-molecular-massorganic acids by six tree species alters the dynamics of calcium and magnesium in soil. Can J Soil Sci 96:199-206

Opfergelt S, Burton KW, Georg RB, West AJ, Guicharnaud RA, Sigfusson B, Siebert C, Gislason SR, Halliday AN (2014) Magnesium retention on the soil exchange complex controlling $\mathrm{Mg}$ isotope variations in soils, soil solutions and vegetation in volcanic soils, Iceland. Geochim Cosmochim Ac 125:110-130

Pearson JN, Rengel Z, Jenner CF, Graham RD (1995) Transport of zinc and manganese to developing wheat grains. Physiol Plantarum 95:449-455

Peng YY, Liao LL, Liu S et al (2019) Magnesium Deficiency Triggers SGR-Mediated Chlorophyll Degradation for Magnesium Remobilization. Plant Physiol 181:262-275

Pokharel R, Gerrits R, Schuessler JA, Floor GH, Gorbushina AA, von Blanckenburg F (2017) Mg Isotope Fractionation during Uptake by a Rock-Inhabiting, Model Microcolonial Fungus Knufia petricola at Acidic and Neutral pH. Environ Sci Technol 51:9691-9699

Pokharel R, Gerrits R, Schuessler JA, Frings PJ, Sobotka R, Gorbushina AA, von Blanckenburg F (2018) Magnesium Stable Isotope Fractionation on a Cellular Level Explored by Cyanobacteria and Black Fungi with Implications for Higher Plants. Environ Sci Technol 52:12216-12224

Ra K, Kitagawa H (2007) Magnesium isotope analysis of different chlorophyll forms in marine phytoplankton using multicollector ICP-MS. J Anal Atom Spectrom 22:817-821

Ra K, Kitagawa H, Shiraiwa Y (2010) Mg isotopes in chlorophylla and coccoliths of cultured coccolithophores (Emiliania huxleyi) by MC-ICP-MS. Mar Chem 122:130-137

Saito T, Kobayashi N, Tanoi K, Iwata N, Suzuki H, Iwata R, Nakanishi TM (2013) Expression and Functional Analysis of the CorA-MRS2-ALR-Type Magnesium Transporter Family in Rice. Plant Cell Physiol 54:1673-1683

Schmitt AD, Vigier N, Lemarchand D, Millot R, Stille P, Chabaux F (2012) Processes controlling the stable isotope compositions of $\mathrm{Li}, \mathrm{B}, \mathrm{Mg}$ and $\mathrm{Ca}$ in plants, soils and waters: $\mathrm{A}$ review. C R Geosci 344:704-722
Shaul O (2002) Magnesium transport and function in plants: the tip of the iceberg. Biometals 15:309-323

Shaul O, Hilgemann DW, de-Almeida-Engler J, Van Montagu M, Inze D, Galili G (1999) Cloning and characterization of a novel $\mathrm{Mg}^{2+} / \mathrm{H}^{+}$exchanger. Embo J 18:3973-3980

Tang RJ, Luan S (2017) Regulation of calcium and magnesium homeostasis in plants: from transporters to signaling network. Curr Opin Plant Biol 39:97-105

Tanoi K, Saito T, Iwata N, Kobayashi N, Nakanishi T (2011) The analysis of magnesium transport system from external solution to xylem in rice root. Soil Sci Plant Nutr 57:265-271

Tanoi K, Kobayashi N, Saito T et al (2014) Effects of magnesium deficiency on magnesium uptake activity of rice root, evaluated using ${ }^{28} \mathrm{Mg}$ as a tracer. Plant Soil 384:69-77

Teng FZ (2017) Magnesium isotope geochemistry. Rev Mineral Geochem 82:219-287

Teng FZ, Wadhwa M, Helz RT (2007) Investigation of magnesium isotope fractionation during basalt differentiation: implications for a chondritic composition of the terrestrial mantle. Earth Planet Sc Lett 261:84-92

Tiryakioğlu M, Yildirim M, Karanlik S (2014) Macronutrient concentration and remobilization in spring wheat organs during grain filling. Turk J Agric For 38:488-494

Verbruggen N, Hermans C (2013) Physiological and molecular responses to magnesium nutritional imbalance in plants. Plant Soil 368:87-99

Wiggenhauser M, Bigalke M, Imseng M, Keller A, Archer C, Wilcke W, Frossard E (2018) Zinc isotope fractionation during grain filling of wheat and a comparison of zinc and cadmium isotope ratios in identical soil-plant systems. New Phytol 219:195-205

Willows RD (2007) Chlorophyll synthesis. In: Wise RR, Hoober JK (eds) The structure and function of plastids. Springer, Dordrecht, pp 295-313

Wombacher F, Eisenhauer A, Heuser A, Weyer S (2009) Separation of $\mathrm{Mg}, \mathrm{Ca}$ and $\mathrm{Fe}$ from geological reference materials for stable isotope ratio analyses by MC-ICP-MS and double-spike TIMS. J Anal Atom Spectrom 24:627-636

Yoneyama T, Gosho T, Kato M, Goto S, Hayashi H (2010) Xylem and phloem transport of $\mathrm{Cd}, \mathrm{Zn}$ and $\mathrm{Fe}$ into the grains of rice plants (Oryza sativa L.) grown in continuously flooded Cdcontaminated soil. Soil Sci Plant Nutr 56:445-453

Yoneyama T, Ishikawa S, Fujimaki S (2015) Route and regulation of zinc, cadmium, and iron transport in rice plants (Oryza sativa $L$.) during vegetative growth and grain filling: metal transporters, metal speciation, grain Cd reduction and $\mathrm{Zn}$ and Fe biofortification. Int J Mol Sci 16:19111-19129

Young ED, Galy A (2004) The isotope geochemistry and cosmochemistry of magnesium. Rev Mineral Geochem 55:197-230

Publisher's note Springer Nature remains neutral with regard to jurisdictional claims in published maps and institutional affiliations. 